\title{
Central Coercion or Local Autonomy? A Comparative Analysis of Policy Instrument Choice in Refugee Settlement Policies.
}

\author{
Vilde Hernes* \\ *Department of Political Science, University of Oslo, Oslo, Norway \\ Vilde Hernes. E-mail: vilde.hernes@stv.uio.no
}

\section{Biographical note}

Vilde Hernes is a PhD fellow at the University of Oslo, Department of Political Science. Her research and teaching cover public policy and design, central-local governance, organizational theory and immigrant integration policies.

\begin{abstract}
Although existing literature on central-local governance includes comprehensive studies on how constitutional and financial frameworks regulate local government autonomy, this study seeks explanations for the introduction or absence of central coercion within these frameworks. The analysis studies six processes of policy instrument choice with different outcomes in Norway, Denmark and Sweden in the field of refugee settlement. It finds that a uniform perception of crisis and political compromises make political parties abandon their political-ideological standpoints relating to central-local governance. Additionally, the success and failure of political strategies of obfuscation and of dividing the opposition help to explain the different outcomes. The study reveals differences in the political salience of central-local governance in three countries that have systematically been categorized in the same groups in central-local studies. Consequently, more studies on how and why local autonomy is regulated within national frameworks are necessary to understand the actual autonomy that local governments enjoy.
\end{abstract}

Keywords: central-local governance; local autonomy; policy instrument choice; refugee settlement; comparative analysis. 


\section{Introduction}

A paradox of central-local government relations is that although local autonomy is frequently portrayed as a highly desirable feature (Ladner, Keuffer, and Baldersheim 2016, 348), the more central government decentralizes services provided in important policy fields, the more it is tempted to control local governments in their role as implementers of national policies (Haveri 2015, 139). Kröger $(2011,150)$ calls this “the quarrelsome relatives' paradox since central government must balance the often opposing values of local autonomy and central control.

In the existing central-local governance literature, two under-explored areas stand out. First, existing literature on central-local relations mainly focuses on the constitutional and financial frameworks for local government, and on the different functions for which the latter are responsible (Sellers and Lidström 2007; Pierre 1990; Goldsmith and Page 2010). Although important, studies of national frameworks provide only a partial picture of local autonomy (Fleurke and Willemse 2006, 71-2). Goldsmith $(2002,92)$ proposes that central control over local government has shifted from direct control using constitutional frameworks to more indirect control exercised through the regulation of policies, for example through policy instruments directed at municipalities. Second, existing cross-case comparisons of local autonomy are mostly descriptive and do not attempt to explain cross-national differences (Blom-Hansen 1999, 237). Thus, scholars have called for studies explaining the varying degrees of local autonomy in different countries (Ladner, Keuffer, and Baldersheim 2016, 348). This article addresses these gaps by asking: what explains the introduction or absence of central coercive policy instruments towards municipalities in central-local governance?

The policy-instrument literature has mainly focused on the interface between the government as a whole and civil society (Hood and Margetts 2007), and on relations between the EU and its member states (Kassim and Le Galès 2010). There is unexploited potential in 
applying this literature to intra-governmental relations (Hood 2007), and more explicitly to the central-local government interface. Additionally, the factors driving the choice of policy instrument have not been sufficiently explored (Hood 2007; Lascoumes and Le Gales 2007). Lascoumes and Le Gales (2007) argue that policy instrument choice is not just a functionalist exercise or secondary issue in policy analysis, but is instead a major political issue deserving closer attention.

The empirical analysis examines six policy processes in Scandinavia involving central-local government instruments in the field of refugee settlement. It investigates whether, and how, political ideology, external support, crisis and political strategies influence whether or not a coercive instrument is applied. In Norway, Denmark and Sweden, municipalities play an important role in refugee settlement and integration, yet these countries have developed fundamentally different models of refugee settlement (Borevi and Bengtsson 2014), applying different instruments which directly affect municipal autonomy. Denmark introduced central allocation of refugees to municipalities as early as 1999 . The Norwegian settlement model, though repeatedly debated and contested, continues to be based on voluntary agreements between central and local government. After rejecting a coercive model in 2009, Sweden followed the Danish example by gradually introducing, in 2014 and in 2016, central allocation of refugees who could not find their own housing. In contrast to the Norwegian and Danish settlement models, the Swedish settlement model allows refugees to self-settle. Those who do not find their own housing are settled with government assistance. This study is limited to the study of the central-local steering of publicly assisted settlement.

The article's comparative research design, with variation on the dependent variable, along with similar central-local government structures, provides suitable cases to explain policy instrument choice. First, when examining the central policy instruments used to restrict local autonomy, the constitutional and financial frameworks regulating the leeway enjoyed by 
central governments should remain constant. Norway, Denmark and Sweden are all unitary welfare states and are consistently classified within the same categories in studies of centrallocal government relations (for an overview, see Sellers and Lidström 2007). They also share political, historical, cultural, and economic features (Haveri 2015, 138; Karlsson 2015, 22), making them suitable cases for comparative analysis of central-local policy instrument choice. Second, the chosen policy processes within the field of refugee settlement explicitly address the question of how actors prioritize between instruments promoting central coercion as opposed to local autonomy. The proposals for instrument change involve a turn from the use of softer governance instruments (privatization, persuasion, voluntary contracts) to more traditional authoritarian instruments (legislative obligation of services). Finally, the six selected processes resulted both in policy change and non-change, showing variation in the dependent variable.

The paper first presents theoretical expectations in regard to central instrument choice. Subsequently, the comparative research design is described, followed by an empirical account of the six policy processes under scrutiny. The discussion examines how political ideological positions, crisis, external support, and the use of different political strategies help to understand the different outcomes, and explains how the findings offer new insights into central-local government relations.

\section{Theory - explaining policy instrument choice in central-local governance}

A notable trend in Europe is the growing consolidation of local governments (Ladner, Keuffer, and Baldersheim 2016). However, the 'rise of local autonomy' may be exaggerated. Fleurke and Willemse $(2006,71)$ argue that although studies of constitutional and financial frames provide important insight into central-local steering, these macro indicators offer only a partial picture of local autonomy. As an example, although Norway, Denmark and Sweden 
are systematically ranked as countries with high levels of local autonomy, Haveri $(2015,139)$ emphasizes that Scandinavian local governments are autonomous on the one hand and an integrated part of the state administration on the other. Due to their important role as implementers of national welfare policies, local governments are more susceptible to state interventions (Haveri 2015, 140). Consequently, the operationalization of these policies through policy instruments is crucial for de facto local autonomy (Baldersheim and Smith 2011, 9).

Salamon $(2002,25)$ defines coercion as the extent to which an instrument restricts or obligates actors as opposed to encouraging or discouraging a particular behaviour. The constitution regulates the possibility of imposing coercive instruments on local government, but all the Scandinavian countries are unitary states, which means that the central state may mandate implementation of tasks by its subunits. However, the Scandinavian central governments' leeway to impose coercive instruments on municipalities is somewhat restricted by the principle of proportionality. The principle states that policy instruments that restrict local autonomy should be applied only if they are necessary to fulfil important national goals, and that the least restrictive instruments should be preferred (Feltenius 2015, 309). In this regard, the trend towards central steering is puzzling, raising the following question: what explains the introduction of new, coercive policy instruments in central-local steering?

\section{Political ideologies and parliamentary composition}

Different political ideologies favour certain instruments. In earlier studies of policy instrument choice, King (2007) and Bache (2010) demonstrated the importance of partypolitical values. Several studies addressing Scandinavian parties' and political representatives' positions on central-local government relations identify clear party differences which are consistent with the classical left-right dimension. Parties on the left are more inclined to approve of central steering than their centre- and right-wing counterparts 
(Karlsson 2015; Hansen and Klausen 2002; Blom-Hansen et al. 2012; Sørensen and Vabo 2005). Thus, coercive instruments are expected to be introduced when left-oriented parties are in government and, conversely, rejected when right- and centred-oriented parties are in power.

The political parties' positions will ultimately decide the outcome of a policy process; however, party ideology is not the only variable that determines political positions (Karlsson, 2015). Subsequently three factors which are expected to influence political parties' positions towards central coercion, and possibly also explain divergence from the parties' initial ideological views on central-local governance, are presented.

\section{Changes in times of crisis}

Historical institutionalism posits that leeway for radical change from previous policies is limited. However, changes or leaps from the current path are possible in times of crisis or what are known as 'critical junctures' (Thelen 1999, 386-88). Crises tend to demand strong central leadership, direction and control (Christensen, Lægreid, and Rykkja 2016, 7), hence a crisis could legitimize the introduction of new, central coercive instruments. Accordingly, a crisis is expected to open a window for policy change.

\section{Support or opposition from experts and target groups}

Palier $(2007,99)$ claims that new instruments must be subject to a relatively broad consensus in order to be adopted. King $(2007,112-113)$ identifies two important factors when examining policy instrument choice: 1) convergent expert knowledge and 2) support or opposition from the target groups. First, a unified or divergent expert community could be a proxy for ascertaining how feasible the proposed policy instrument and its potential consequences are perceived to be. If knowledgeable actors within the field question whether the proposed solution will generate the desired effects, politicians might discard the proposed change. Second, Zahariadis $(2014,34)$ writes that politicians often view the support or opposition of 
interest groups as indicators of consensus or dissent in the broader political arena. Thus, support from the municipalities as a target group may mitigate the political risk of introducing coercive policy instruments. Consequently, support from experts and target groups is expected to enhance the possibility for policy change.

\section{Political strategies}

If the government, or advocates within the government, want to introduce a new policy instrument, their strategy may be decisive for the outcome. For example, a minority government or parties within a coalition government often need to persuade and negotiate both with coalition parties and the opposition to ensure a majority in parliament. The government's strategy could be expected to affect not only other parliamentary parties' positions, but also those of external actors, and especially the target group of the policies. Blom-Hansen et al. $(2012,75)$ present different strategies (implemented by the advocates of change) for quelling potential opposition: compensation, obfuscation and 'divide and rule' tactics. The compensation strategy seeks to reduce resistance by linking two or more issues, e.g. a 'package deal'. In the empirical analysis, an example of this might be when a coercive instrument constitutes only one element of a larger reform. Opponents may then accept the coercive element as part of a larger compromise. The obfuscation strategy uses positive framing to make the potentially negative consequences of a proposed change less visible, thus easing the coercive element. How explicitly the advocates for change present the coercive element and its consequences may affect the course of the debates and ultimately support for it both on the part of political parties and other actors. Thus, a successful obfuscation of the proposed instrument's potentially negative consequences for the target group could facilitate the introduction of the coercive instrument. Finally, the alliance-building 'divide and rule' strategy exploits potential cleavages in the opponents' coalitions. By framing the issue in a particular way, advocates can pit potential opponents against each other. In sum: a 
government's use of the three strategies - compensation, obfuscation and 'divide and rule' - is expected to enhance the possibility for policy change.

\section{Research design}

The Scandinavian countries share strong political, social, cultural and economic similarities, making them suitable cases for cross-country comparison, as the empirical analysis keeps important contextual factors (relatively) constant (Blom-Hansen et al. 2012, 78; Baldersheim and Ståhlberg 2002, 78). Their central-local structures, which include comprehensive welfare states where municipalities play a crucial role (Hansen and Klausen 2002), and their similar political systems and party composition (Blom-Hansen 1999, 243), enable the examination of how other factors within these constitutional and financial frameworks affect policy outcomes. More particularly concerning refugee policies, in all three countries municipalities play an important role in offering post-settlement integration programmes (Brochmann et al. 2012, 246). Still, the three countries have developed very different models for refugee settlement (Borevi and Bengtsson 2014, 2), and thereby offer variation in the dependent variable: namely use of coercive policy instruments towards the municipalities. To test the causal mechanisms, variation in the dependent variable, including cases of non-change, is crucial (Mahoney and Goertz 2004, 653). Additionally, the analysis combines detailed withincase analysis with cross-case comparison, enabling the assessment of complex causal relations (George and Bennett 2005, 19-22).

The selected policy processes include proposals to introduce a coercive policy instrument, namely legislation empowering a central authority to decide the allocation of refugees among the municipalities. Although the details of the proposed legislation vary from case to case, all proposals involve a clear restriction of local autonomy, thus altering the central-local relationship within the policy field. 
Current literature on Scandinavian settlement policies includes analyses of former processes in force until around 2010 (Borevi and Bengtsson 2014; Brochmann et al. 2012). This article will therefore focus mainly on more recent cases that have not yet been studied. The first Scandinavian country to introduce coercive policy instruments was Denmark in 1999. In Sweden, the question has been on the political agenda several times in recent years. In 2010, a coercive settlement model was proposed and rejected. Still, in the following years, the government gradually introduced new coercive instruments: first, in 2014, central allocation of solitary under-aged refugees (SUARs); and more recently, in 2016, central allocation of all refugees who do not self-settle. In Norway, in 2011, the government sent a proposal introducing central allocation of refugees for public hearing, but the proposal did not succeed as a proposition to parliament after the hearing. The refugee crisis of 2016 resulted, as mentioned above, in a change in the Swedish model. Due to the similarities in the Swedish and Norwegian processes of 2010 and 2011, the analysis includes the Norwegian case of 2016 as a negative case, to investigate why coercive instruments were not even on the formal political agenda at this time. The case selection applies Mahoney and Goertz' (2004) possibility principle pertaining to instances where there might have been a window of opportunity for change, but where a formal policy process never took place.

Table 1. Selected policy processes and data

Policy documents and transcripts from the public hearings and parliamentary debates constitute the data for the empirical analysis. The parliamentary debates provide information on the political parties' positions in the policy processes, including in-depth justification of those positions. In Scandinavia, public hearings constitute an arena for actors to state their opinion about a proposed policy change in which the actors evaluate the proposal's appropriateness and feasibility along with its potential effects. Accordingly, public hearings provide information on how other experts within the field assess the proposed instruments: 
namely other ministries, professional agencies, regional prefects (all classified as "central actors" in the empirical analysis), and refugee and other organisations with possible relevant knowledge (classified as "organizations"). Additionally, public hearings help to identify support and opposition in the target group, the municipalities and their interest organizations. In Norway, the 2011 proposal did not make it to parliament after the public hearing, and the decision to keep the current settlement model in the 2016 White Paper was not subject to any formal discussion. To understand why these cases did not result in change, interviews both with administrative and political officials involved in both processes were conducted.

\section{Empirical analysis}

\section{Denmark}

In Denmark, until 1999, refugees either found their own housing or received settlement assistance from the Danish Refugee Council, a humanitarian organization which was also responsible for integration activities during the first 18 months after the refugee was granted a residence permit (Damm 2005, 5-7). In December 1997, the Danish minority government consisting of the Social Democrats (SD) and Danish Social Liberal party (RV) presented a proposition to parliament that entailed a major reform of integration and asylum policies. As part of this reform, the proposed Integration Act would oblige the municipalities to provide a three-year introduction program for refugees, and outlined a new settlement model that restricted the latter's right to self-settlement and gave a central agency the authority to allocate refugees to the municipalities. 
In the 1998 public hearing, 40 actors responded, although twelve actors had no comments. ${ }^{1}$ The actors were unanimously in favour of the hearing proposal when it came to the question of central-local steering. Although several actors disputed other elements in the proposed Integration Act (particularly the restriction on the refugees' right to self-settle), all actors supported the proposal to give a central agency the authority to allocate refugees among the municipalities. The main argument in the public hearing was that a centrally coercive model would lead to a more dispersed and fairer settlement among the municipalities.

However, this unified support was not reflected in the parliamentary debates. The leftwing parties and the Christian Democrats (SF, EL and CD) supported the proposal that greater coercion should be imposed on the municipalities, but opposed the abolition of the refugees' right to self-settle. The conservative-liberal parties (V and KF) and the right-wing parties (DF and FP) strongly opposed constraints on municipal autonomy. However, after negotiations in the parliamentary committee, the Integration Act was passed with more or less the same settlement model as in the first draft. $^{2}$ In the final ballot, the left and right-wing parties voted against (though on different grounds). V and KF voted blank; however, the parliamentary debate reveals that this was not because they opposed the settlement model, but was due to a disagreement regarding another element in the integration and asylum reform, namely family reunification.

\footnotetext{
${ }^{1}$ The distribution of responses comprised three central actors, 18 organizations and three municipal actors. The municipal response to the Danish hearing was significantly lower than in the Norwegian and Swedish hearings. However, Denmark does not normally request that all or parts of the municipal community respond (although the hearings are open to all of them), as is the case in Norway and Sweden.

${ }^{2}$ Although the parliamentary negotiations included a rhetorical emphasis on how voluntary agreements between the municipalities should first be tested, the coercive elements in the legislation remained the same.
} 


\section{Sweden}

The first Swedish settlement model was founded on voluntary agreements between a central agency and the municipalities, but the 1994 reform introduced self-settlement as a new principle. Although subject to many debates since its introduction, the principle of selfsettlement still prevails today (Borevi and Bengtsson 2014). Refugees who did not self-settle continued to be settled through voluntary agreements between central and local government. In 2008, a committee presented a Green Paper proposing a major reform of Swedish integration policy. The committee recommended that the main responsibility for refugee integration be transferred from local to central government (Integration Act), and additionally that refugees who did not self-settle should be centrally allocated (Settlement Act). 115 actors responded to the public hearing, but only 61 commented on the proposed change in the settlement model.

\section{Table 2. Public hearing in Sweden 2008}

A majority of the central stakeholders and organizations supported (or did not directly oppose) central coercion, however several argued that sanctions needed to be included to ensure the desired effects (which the Green Paper did not suggest). The municipalities were divided: supporters called for a fairer dispersal of refugees across the country; others emphasized challenges posed by the current proposal but did not make their own opinion clear; $23 \%$ directly opposed it (including the national municipal organization).

Despite support from the majority of experts and a divided municipal community, the liberal-conservative government (M, C, Fp and KD), with the support of Mp, presented a proposition to parliament that rejected the coercive element proposed in the Green Paper. They argued that the public hearing had exposed challenges with the proposed changes and concluded that the disadvantages outweighed the advantages. In the subsequent parliamentary 
debate, the Socialist Left party (V) motioned to follow the recommendations of the Green Paper, but was overruled.

However, a similar question quickly reappeared on the agenda. In 2011, a committee presented a Green Paper that recommended enforcing the Migration Board's opportunity to allocate SUARs to the municipalities. An increase in SUAR arrivals compared to earlier prognoses had created a shortage of voluntary arrangements for SUAR settlements. This shortage led to expensive temporary settlement options in overloaded municipalities, and long waiting periods for children in temporary accommodation. The public hearing had 45 replies, but two central agencies had no comments.

\section{Table 3. Public hearing in Sweden 2012}

Compared to the 2008 hearing, the Green Paper encountered strong opposition. Support from central actors was rather similar, but a clear majority of organizations and municipalities opposed it. They challenged the argument that the shortage of central-local agreements was not due to municipal willingness, but ability, and feared that forced settlement could have a negative effect on long-term integration. The two supporting municipalities received a high number of SUARs in their community, and therefore argued in favour of a fairer distribution of responsibilities among the municipalities.

Regardless of the overwhelming opposition, the proposition from the liberalconservative government $(\mathrm{M}, \mathrm{C}, \mathrm{Fp}$ and $\mathrm{KD})$ followed the recommendation of the Green Paper. Additionally, all opposition parties, except the right-wing Sweden Democrats (SD) who entered parliament after the 2010 election, supported the proposal, which was passed with $93 \%$ of the votes.

In June 2015, the social-democratic-green government (SD and Mp) presented a ministry proposal for central allocation of refugees who did not self-settle (similar to the 2008-10 proposal). The proposal argued that the voluntary municipal model did not make 
sufficient provision for settlements. Additionally, the prolonged settlement process increased the number of self-settlements in areas that already had large concentrations of refugees. 81 stakeholders replied to the hearing, but 14 did not comment.

\section{Table 4. Public hearing in Sweden 2015}

Overall, the majority supported the proposal. A few municipalities opposed it, but most argued explicitly that coercion was necessary to ensure more dispersed settlement. All political parties, except the Sweden Democrats, supported the proposition, with two modifications: V proposed including sanctions, and the Moderates supported the restriction of municipal autonomy as part of a larger trans-political compromise on integration policies because of the refugee crisis during the fall of 2015 .

\section{Norway}

In Norway, despite an enduring shortfall between supply and demand in refugee settlements during the past 20 years (Hernes and Askim 2017), local government autonomy has been, and still is, the leading principle governing refugee settlement. That principle has, however, been challenged repeatedly. Both in 1990 and 2001, proposals to give central government the authority to allocate refugees to municipalities were rejected (Hernes 2012, 35). In 2011, the question reappeared on the political agenda. A ministry proposal from the Norwegian redgreen government (AP, SV and S) suggested introducing central allocation, as a continuing gap between municipal supply and central demand for settlements had created a queue of refugees waiting for settlement in national asylum centres. 136 actors replied in the public hearing, but 17 did not comment.

Table 5. Public hearing in Norway 2011 
The central actors were divided and, most importantly, the directorate responsible for refugee settlement (IMDi), opposed central settlement allocation. The organizations, however, were predominantly positive. The Norwegian Association for Local Government (KS) strongly opposed central settlement, along with a unanimous municipal community. They argued that the proposal did not address the real problems in the settlement process, which in their opinion derived from the municipalities' inability to settle more refugees, not from a lack of municipal willingness.

After the public hearing, the government did not present the proposal to parliament. Still, the interviews revealed that the process continued within the ministry. The Socialist Left party, with the support of the Social Democrats, formulated a revised proposal. The Centre party, however, was sceptical. Nonetheless, they did not reject the proposal, but wanted to wait until after the local elections in 2011 due to the massive municipal opposition at the public hearing. After the election, however, advocates dropped the ball. The combination of municipal opposition, along with opposition from the ministry's own directorate, weakened the case of those advocating a coercive model, and other non-coercive instruments were prioritized.

Nonetheless, the shortfall between supply and demand for more settlement agreements doubled during the following period of 2011-2014 (Hernes and Askim 2017). During the autumn of 2015, because of the large increase in asylum seekers due to the refugee crisis, the government, via the revised budget, decided to generate a new White Paper on integration within six months. However, an interviewee informed that a political decision had been made that a centrally coercive settlement model was off the table. The interviewee emphasized that one of the governing parties, the Progress Party (Frp), would have found it almost impossible to introduce a coercive settlement model; however, the informant doubted that other political coalitions would have resulted in a different outcome. The general political will to introduce 
central allocation was rather half-hearted, as almost all the political parties (except maybe SV) considered it an electoral risk not worth taking. More importantly, perhaps due to the general perception of crisis in society and public willingness to help during the crisis, the municipalities had opened for more settlements than ever before. Thus, even though Norway experienced a crisis concerning the reception of asylum seekers, this was not the case when it came to refugee settlement. Quite the contrary: in December 2015, the gap between municipal supply and central demand had been closed (temporarily) due to the crisis.

\section{Discussion}

In summary, the empirical analysis reveals that in the cases that resulted in policy change, the introduction of policy instruments was proposed and supported by different parties across the political spectrum. Thus, ideological party positions and parliamentary composition are not sufficient to explain the different outcomes. However, the hypothesis that a crisis correlates with policy change is confirmed, along with the different governments' use of a compensation strategy that entailed offering the opposition 'package deals' to ensure support. The relevance of expert support is more ambiguous, but the support of partial target groups proved crucial to ensure policy change. The hypothesis of applying a strategy of obfuscation in order to succeed is disputed, while the 'divide and rule' tactic appears highly effective in bringing about policy change. The subsequent discussion will elaborate on each of the above-mentioned findings.

\section{Abandoning ideological positions - compromise and crisis}

Earlier studies show how Scandinavian political parties and their representatives have particular ideological positions on central-local steering (Karlsson 2015; Hansen and Klausen 2002; Blom-Hansen et al. 2012, 82; Sørensen and Vabo 2005). The analysis of parliamentary debates supports this notion. Social-democratic parties support coercive instruments for settling refugees, but left-wing parties are the main advocates. The conservative and liberal 
parties are, in principal, sceptical, and right-wing parties find it unacceptable to force the municipalities to settle refugees. Nonetheless, the analysis reveals that the introduction of coercive instruments in Denmark and Sweden was not caused by changes or divergence in government coalitions, but by the fact that some parties that initially opposed coercion on ideological grounds changed their positions. The conservative and liberal parties that had initially argued against central coercion ended up supporting (or not actively opposing) the coercive instrument. Parliamentary debates reveal that these parties' change of position was justified by two considerations, 1) compromise, and 2) a shared perception of a crisis.

First, the governments in both countries used 'package deals' as a compensation strategy (Blom-Hansen et al. 2012). In the Danish and Swedish processes in 2015-16, the coercive instrument was one element in a larger reform of integration and asylum policies. Part of the reason for the conservative and liberal parties' support (or at least for their lack of active opposition), was that the proposed change was part of a larger compromise.

More importantly, parliamentary debates and public hearings reveal that the perceived severity of the problem varied substantially across the cases, and a clear pattern emerges separating the instances of change and non-change. In Sweden, the liberal and conservative parties who rejected central coercion in 2009 voted in favour in 2013 and 2016. The parties who had formerly opposed it explicitly justified their change of position by arguing that the crisis they faced called for a change. Christian democratic representative Désirée Pethrus' statement in the 2016 parliamentary debate illustrated this: 'When we saw the extent of asylum applications, we felt obliged to act. We saw that the voluntary system of municipal agreements, which had previously been encouraged, was no longer sufficient.' (author's translation). In the Danish debates in 1998, all the political parties expressed a shared concern about the highly concentrated settlements. By contrast, in the cases of non-change, the 
severity of the problem was either disputed or actively used as a counterargument by the opponents of coercive instruments.

Although the stated hypothesis - that a crisis could legitimize new, centrally coercive instruments - is confirmed, a modification is necessary. Kingdon $(1984,109)$ emphasizes that a crisis appears when a condition is defined as a problem that requires action and (often new) measures (Kingdon 1984, 109). For instance, Denmark has always received a substantially lower number of asylum seekers than both Norway, and especially Sweden. In the years prior to the 1999 Danish Integration Act, about 3000 refugees were granted a residence permit annually (Danmarks Statistik 2016). In the years leading up to the policy processes in Norway in 2011 and Sweden in 2008-10 (where coercive instruments were rejected), over 6000 (in Norway) and up to 11-25000 (in Sweden) refugees were granted residence permits annually (UDI 2009, 2010; Migrationsverket 2016). Thus, the actual number of refugees who needed settlement assistance was not the decisive factor for change, but rather the political actors' unified perception of the seriousness of the problem.

\section{Norwegian political reluctance to restrict municipal autonomy}

The two cases of non-change in Norway included governments with parties that had a particularly strong sense of ownership over, and negative position towards, central coercion within this field: namely, the agrarian Centre party in the 2011 government and the right-wing Progress Party in 2015. The interviewees believed that these parties' political position made the introduction of coercive instruments difficult. Still, one interviewee pointed to a more generalized reluctance in the political landscape, and doubted that other party coalitions would have introduced a coercive settlement model. What could be the cause of this Norwegian political reluctance to impose central coercion on the municipalities? 
The constitutional and financial frameworks regulating municipal autonomy do not provide the answer. However, although central-local structures in Scandinavia are relatively similar, constitutional protection of municipal autonomy is actually slightly weaker in Norway than in Denmark and Sweden (Sellers and Lidström 2007). One of the Norwegian interviewees presented an interesting observation, declaring that; "In Norway, the principle of municipal autonomy is legally weaker, but politically stronger [than in Denmark and Sweden]" (Interview with Director General", 27.10.2016, author's translation). What the notion of 'politically stronger' entails is debatable; however, earlier studies have shown that central-local relations are politically more salient in Norway than in Sweden and Denmark. The political salience of the central-local issue in Norwegian politics has strong institutional roots. Arter $(2008,69)$ shows how the centre-periphery dimension has played a significant role in the development of the Norwegian party system compared to that of Denmark and Sweden. Additionally, the heated political debate over central coercion during the process of municipal amalgamation in Norway (which one could argue lies at the heart of central-local relations), stands in contrast to the Danish process in 2007 (Blom-Hansen et al. 2012). BlomHansen et al. $(2012,79)$ also point out that Norwegian local governments have a stronger tie to central government because local councils constitute more important recruitment platforms to parliament than they do in Denmark, which could explain why the Norwegian central level is more receptive to local opinions.

One could assume that cross-country differences in the political salience of local autonomy would be reflected in constitutional and financial frameworks. However, these empirical findings indicate that the political salience of central-local relations varies within countries which otherwise share a rather similar approach to the constitutional and financial protection of local autonomy. 


\section{Divergent opposition by experts and target groups}

The Norwegian political reluctance may also be a consequence of differences in external support from relevant actors in the public hearing. Support from external actors may be crucial to reduce the political risk of imposing central coercive policy instruments. King (2007) and Palier $(2007,93)$ highlight the experts' unified perception of an instrument as important for its introduction. The 2015 Swedish and 1998 Danish hearings, which ultimately resulted in change, were rather uniformly evaluated by central actors. In contrast, the Norwegian hearing in 2011, and the Swedish hearings in 2008 and 2012, show polarized expert opinions. The interviewees revealed that the opposition of the Norwegian ministry's

own directorate (IMDi) was a major obstacle to advocates of the coercive instrument, as IMDi pointed to legal, technical and financial challenges with the ministry's proposal (Hernes 2012, 47). The Swedish processes in 2008-10 and 2011-14 suggest that divergent expert opinions enabled the government to pick the arguments best suited to its initial position. In 2008-10, the Swedish government actively used the divergent expert opinions in the public hearing to justify another conclusion than that of the initial Green Paper. The government argued that many actors in the hearing had emphasized the proposal's lack of sanctioning tools and thereby questioned the potential effectiveness of the instruments. Ironically, the actors who pointed to this 'flaw' explicitly stated that they supported the coercive element, but that new legislation should include sanctions, thus proposing to increase the coercive element. Consequently, in the case of polarized expert opinions, the government is perhaps freer to exploit disagreements for its own benefit.

Moving on to the target group, the municipalities, two of the cases that resulted in change support the need for relatively broad consensus in order to introduce a new instrument (Palier 2007, 99). In Denmark, the municipal actors were all positive, and in the Swedish process in 2015-16, $85 \%$ of the municipal actors supported or did not directly oppose it. 
Conversely, the Norwegian hearing proposal, which was rejected in 2011, met with unanimous opposition from the 89 municipalities that replied. Thus, these three cases highlight the relevance of support from the affected target group. However, the Swedish hearing in 2012 challenges the importance of a broad target-group consensus in ensuring change, with $86 \%$ of the municipalities opposing it. Still, parliament passed the law with an overwhelming majority of $93 \%$. Comparing the Swedish hearing in 2012 (with $86 \%$ of municipalities in opposition) with the Norwegian hearing in 2011 (in which $100 \%$ opposed), indicates that the percentage of support is not the decisive element for change; but rather, that having at least some support from the subjects targeted by the coercion is crucial. The Norwegian interviewees believed that if at least some of the municipalities had been supportive, the result would probably have turned out differently, which underlines the impact that unanimous opposition had on the process. Thus, when imposing central coercion, partial support from the municipalities as a target group is crucial. This observation is supported by another study, which emphasized partial municipal support as decisive in explaining why the Danish amalgamation process in 2007 succeeded, while a similar process in Norway stranded (Blom-Hansen et al. 2012).

Nonetheless, why did Norway experience a unified municipal opposition, while municipal actors in Denmark and Sweden supported it or were divided?

\section{The (ineffective) art of obfuscation and the 'divide and rule' tactic}

In the ministry hearing proposal in 2011, the Norwegian government applied a strategy of obfuscation, downplaying the narrative of 'the central government imposing obligations on the municipalities'. The ministry did not want to name and shame the municipalities that settled a relatively small share of refugees; on the contrary, the Norwegian proposal praised the municipal community, stating that; "The municipalities have in recent years made a great 
effort to settle refugees". The interviews revealed that this positive framing by policymakers was deliberate, although it was contested within the ministry. As the government relied upon municipal goodwill in the existing model, they did not want to upset the municipalities. However, the strategy of implicitness, or obfuscation, did not succeed. The opposing actors explicitly challenged the proposal's implicit problem definition (Hernes 2012), as illustrated by the municipal organization KS' (2011) statement in the public hearing: "It seems that the actual ability to implement, and not the [municipal] will, constitutes the limiting factor. This will not be solved by coercion". Thus, the attempt to obfuscate the coercive element and soothe the opposition using positive framing did not succeed.

The Danish and Swedish governments chose a different strategy. The initial proposals and advocates in favour of coercion in the parliamentary debates explicitly highlighted that it was unacceptable that some municipalities were not taking their share of the responsibility for refugee settlement, thus exploiting the potential breach in the target group's coalition. This 'divide and rule' tactic worked, as municipalities who were responsible for a relatively large number of refugee settlements supported the coercive instrument to ensure a better distribution. Additionally, framing the instrument not as a tool of central coercion, but as an instrument promoting a fair municipal distribution of responsibilities may have had a legitimizing effect.

An earlier study of central-local relations concluded that the Danish government's successful application of the strategies of obfuscation and 'divide and rule' resulted in a reform, compared to a failed process in Norway (Blom-Hansen et al. 2012). The analysis of our cases supports the importance of dividing the opposition. However, it illustrates how explicitness about the consequences (here, an erosion of municipal autonomy), instead of obfuscation, functioned as a precondition for applying the 'divide and rule' tactic. Thus, an 
alternative strategy to obfuscation is to spell out the consequences in cases where a proposed change divides the opposition into potential 'winners' and 'losers'.

\section{Conclusion}

When delegating responsibilities to subunits, the temptation to control and steer arises. Balancing the principles of local autonomy and central control is a challenging political manoeuvre, but what influences the decision to prioritize one over the other?

This article examines explanations for the introduction or absence of central coercive policy instruments towards local government. The comparative research design analyses six policy processes in Scandinavia where the introduction of policy instruments involving central coercion is put on the political agenda, focusing on the case of refugee settlement policies. The study contributes to the central-local literature by addressing two areas that have been insufficiently explored: 1) studies explaining cross-country differences, and 2) studies of how local government is regulated within constitutional and financial frames.

First, although the analysis supports earlier research stating that political parties have ideological preferences concerning central-local relations, it illustrates how ideology is put aside in times of perceived crisis and due to political compromises entered into as part of larger reforms. Thus, crises and political compromises largely explain why many Danish and Swedish political parties who ideologically oppose restricting municipal autonomy, ultimately supported the central allocation of refugees. Additionally, different political strategies in terms of how the instrument was presented by central government, which greatly affected the outcomes, help explain cross-national differences in municipal opposition and support. While the Norwegian attempt to obfuscate the consequences of the coercive element failed, the Danish and Swedish advocates used a different tactic of 'divide and rule', explicitly highlighting that the proposal would benefit some municipalities over others compared to the 
status quo, which led to parts of the municipal community supporting the proposed coercive element.

The study only analyses one policy field, refugee settlement, which is part of the overall immigration debate and as such a particularly contentious political issue (Koopmans \& Statham, 2000). The significance of a policy sector's political contention on the centrallocal dilemma, compared to less contentious policy issues, may affect the relative importance of the different theoretical factors. As shown in the case studies, the relevance of the expert opinions is more ambiguous, while the political strategies of compensation and dividing the opposition to obtain at least partial support from the target group appears crucial. In other less contentious policy fields, the relevance of expert opinions might weigh more heavily (Culpepper, 2010), possibly decreasing the relative importance of political strategies and target group support.

Second, regarding the regulation of local autonomy within the constitutional and financial frameworks, an important finding is Norway's political reluctance to restrict municipal autonomy, and indeed other studies support the observation that central-local relations are more politically salient in Norway than in Denmark and Sweden (Arter 2008; Blom-Hansen et al. 2012). One might assume that cross-country differences in the political salience of local autonomy would be reflected in constitutional and financial frameworks. However, the study reveals differences in the political salience of central-local governance in three countries that have systematically been categorized in the same groups in comparative central-local studies (Sellers and Lidström 2007); thus, similar variation may also occur within other countries that are grouped together on central-local indices. Consequently, the question arises concerning such indices: how much variation is possible within these groups? For example, according to several central-local indices, responsibility for a policy field implies a higher 'autonomy 
score'. However, if the policy field is coercively regulated by the central government, one might question whether the increased responsibility enhances or hampers local autonomy.

To conclude, although the constitutional and financial frameworks are relevant measures of local autonomy, it should be emphasized that they provide a partial picture of local autonomy and only serve to regulate the potential autonomy that local governments may have (Fleurke and Willemse 2006, 75). Consequently, studies examining how and why local autonomy is regulated within these frameworks is necessary to understand the actual degree of autonomy that local governments enjoy. 


\section{References}

Arter, David. 2008. Scandinavian politics today. Manchester: Manchester University Press.

Bache, Ian. 2010. "Partnership as an EU Policy Instrument: a Political History." West European Politics 33 (1):58-74.

Baldersheim, Harald, and Eivind Smith. 2011. Lokalt demokrati uten kommunalt selvstyre? Oslo: Abstrakt forlag.

Baldersheim, Harald, and Krister Ståhlberg. 2002. "From Guided Democracy to Multi-Level Governance: Trends in Central-Local Relations in the Nordic Countries." Local Government Studies 28 (3):74-90.

Blom-Hansen, Jens. 1999. "Policy-Making in Central-Local Government Relations: Balancing Local Autonomy, Macroeconomic Control, and Sectoral Policy Goals." Journal of public policy 19 (03):237-64.

Blom-Hansen, Jens, Peter Munk Christiansen, Anne Lise Fimreite, and Per Selle. 2012. "Reform Strategies Matter: Explaining the Perplexing Results of Regional Government Reforms in Norway And Denmark." Local Government Studies 38 (1):71-90.

Borevi, Karin, and Bo Bengtsson. 2014. "The Tension Between Choice and Need in the Housing of Newcomers: a Theoretical Framework and an Application on Scandinavian Settlement Policies." Urban Studies 52 (14): 2599-2615.

Brochmann, Grete, Anniken Hagelund, Karen Borevi, Heidi Vad Jønsson, and Klaus Petersen. 2012. Immigration policy and the Scandinavian Welfare State, 1945-2010. Basingstoke: Palgrave Macmillan.

Christensen, Tom, Per Lægreid, and Lise H. Rykkja. 2016. "Organizing for Crisis Management: Building Governance Capacity and Legitimacy." Public administration review 76 (6):887-97.

Culpepper, P. D. (2010). Quiet politics and business power: Corporate control in Europe and Japan. New York: Cambridge University Press.

Damm, Anna Piil. 2005. The Danish Dispersal Policy on Refugee Immigrants 1986-1998: A Natural Experiment? Aarhus: Department of Economics, Aarhus School of Business.

Danmarks Statistik. 2016. "Asylansøgninger og opholdstilladelser." Accessed 10.01. 2016

Feltenius, David. 2015. "Multi-Level Governance as 'Post-Constitutional'Politics: Subnational Actors and the Swedish Constitution." Local Government Studies 41 (2):301-19.

Fleurke, Frederik, and Rolf Willemse. 2006. "Measuring Local Autonomy: A DecisionMaking Approach." Local Government Studies 32 (1):71-87.

George, Alexander L., and Andrew Bennett. 2005. Case Studies and Theory Development in the Social Sciences. London: MIT Press.

Goldsmith, Michael. 2002. "Central Control over Local Government - a Western European Comparison." Local Government Studies 28 (3):91-112.

Goldsmith, Michael, and Edward C Page. 2010. Changing Government Relations in Europe: from Localism to Intergovernmentalism. New York: Routledge.

Hansen, Tore, and Jan Erling Klausen. 2002. "Between the Welfare State and Local Government Autonomy." Local Government Studies 28 (4):47-66.

Haveri, A. 2015. "Nordic Local Government: A Success Story, but Will It Last?" International Journal of Public Sector Management 28 (2):136-49.

Hernes, Vilde. 2012. "Hvem skal ha det siste ordet -staten eller kommunen? En analyse av høringsrunden om ny bosettingsordning for flyktninger." Master thesis, University of Oslo. 
Hernes, Vilde, and Jostein Askim. 2017. "Bosetting av flyktninger: Hvem bør få siste ord, kommunene, staten eller flyktningen selv?" In Smartere styring, edited by Jostein Askim, Kristoffer Kolltveit and Per Gunnar Røe. Oslo: Universitetsforlaget.

Hood, Christopher. 2007. "Intellectual Obsolescence and Intellectual Makeovers: Reflections on the Tools of Government After Two Decades." Governance 20 (1):127-44.

Hood, Christopher, and Helen Margetts. 2007. The Tools of Government in the Digital Age. New York: Palgrave Macmillan.

Karlsson, David. 2015. "Local Autonomy or National Equality? A Conflict of Values and Interests for Political Leaders." Regional \& Federal Studies 25 (1):19-44.

Kassim, Hussein, and Patrick Le Galès. 2010. "Exploring Governance in a Multi-Level Polity: A Policy Instruments Approach." West European Politics 33 (1):1-21.

King, Desmond. 2007. "The American State and Social Engineering: Policy Instruments in Affirmative Action." Governance 20 (1):109-26.

Kingdon, John W. 1984. Agendas, Alternatives, and Public Policies. Boston: Little, Brown and Co.

Kröger, Teppo. 2011. "Retuning the Nordic Welfare Municipality." International Journal of Sociology and Social Policy 31 (3/4):148-59.

KS. 2011. "Høringsuttalelse. Oslo: Kommunenes Sentralforbund.

Ladner, Andreas, Nicolas Keuffer, and Harald Baldersheim. 2016. "Measuring Local Autonomy in 39 Countries (1990-2014)." Regional \& Federal Studies 26 (3):321-57.

Lascoumes, Pierre, and Patrick Le Gales. 2007. "Introduction: Understanding Public Policy through Its Instruments-From the Nature of Instruments to the Sociology of Public Policy Instrumentation." Governance 20 (1):1-21.

Mahoney, James, and Gary Goertz. 2004. "The Possibility Principle: Choosing Negative Cases in Comparative Research." American Political Science Review 98

Migrationsverket. "Beviljade uppehållstillstånd 1980-2015." Migrationsverket.

Palier, Bruno. 2007. "Tracking the Evolution of a Single Instrument Can Reveal Profound Changes: The Case of Funded Pensions in France." Governance 20 (1):85-107.

Pierre, Jon. 1990. "Assessing Local Autonomy." In Challenges to local government, edited by Desmond S. King and Jon Pierre. London: Sage Publications.

Salamon, Lester M. 2002. "The New Governance and the Tool of Public Action: An Introduction." In The Tools of government : a guide to the new governance, edited by Odus V. Elliott. Oxford: Oxford University Press.

Sellers, Jefferey M., and Anders Lidström. 2007. "Decentralization, Local Government, and the Welfare State." Governance 20 (4):609-32.

Sørensen, Rune J, and Signy Irene Vabo. 2005. "Hvorfor staten overtar styringen fra kommunene." Tidsskrift for Samfunnsforskning 46 (4):503-36.

Thelen, Kathleen. 1999. "Historical Institutionalism in Comparative Politics." Annual Review Political Sience 2:369-404.

UDI. 2009. "Årsrapport 2009. Tall og fakta." . 2010. "Årsrapport 2010. Tall og fakta."

Zahariadis, Nikolaos. 2014. "Ambiguity and Multiple Streams." In Theories of the policy process, edited by Christopher M. Weible and Paul A. Sabatier. Boulder, Colo: Westview Press. 